\title{
Forget the Transnational State
}

\author{
Paul Cammack
}

Manchester Metropolitan University

\section{Acknowledgements}

I would like to thank Greig Charnock, Denis Murphy, Alex Nunn and Iain Pirie for their comments, and Maja Zehfuss for inspiring the title. 


\section{Forget the Transnational State}

Mindsets ... are exceedingly difficult to break even when confronted with logical inconsistencies and problems of empirical validity [Robinson, 2004, p. 93]

\section{Introduction}

William Robinson has argued energetically over recent years that the rise of transnational capital is leading to the emergence of a 'transnational capitalist class' (TCC) and a 'transnational state' (TNS). ${ }^{1}$ He argues that we are in a period of transition from the 'nation-state phase of world capitalism ... to a transnational phase' [Robinson, 2004: 5]; anyone who thinks otherwise is a victim of 'nationstate centrism' - a mindset they need to abandon [ibid: 93]. But the 'summary statement' of his work on globalization from which these phrases are taken largely a compilation from earlier essays - is full of logical inconsistencies, and offers little evidence in support of the case for a 'transnational state', despite his having promised before and acknowledged since that it might be time to provide some [Robinson, 2002, p. 500; 2005b, p. 5]. So I argue here that it is time for Robinson to abandon his own 'transnationalist' mindset, and accept the less arresting but more persuasive conclusion that national states have a changing but continuing role in the global capitalist system, one in which they are oriented and supported by an increasingly interlocked network of global institutions that do not show any tendency to evolve into a transnational state [Cammack, 2006c]. The idea of such a state is an unnecessary and unhelpful diversion, and a barrier to understanding, and should be renounced.

\section{Global capitalism}

Robinson identifies himself with the global capitalism thesis or school, which argues that 'globalization represents a new stage in the evolving world capitalist system that came into being some five centuries ago', and 'can be explained largely by a methodologically prior, materialist theory of capitalism' [2]. ${ }^{2}$ His

1 Prior to the monograph examined here [Robinson 2004], see for example Robinson 1998, 2000, 2002. Subsequent to it, see Robinson 2005a, 2005b, 2006.

2 He identifies four epochs in the history of capitalism: mercantilism and primitive accumulation (1492-1789); competitive or classical capitalism (1789-late C19th); 'corporate ("monopoly") capitalism' (late C19th-1970s); and 'globalization', still in its early phases [4-5]. 
initial theoretical formulation of globalization does not invoke the idea of transnationalism, but states that it 'can essentially be seen as the near culmination of a centuries-long process of the spread of capitalist production around the world and its displacement of all precapitalist relations, bringing about a new form of connection between all human beings around the world' [2]:

by the early twenty-first century the vast majority of peoples around the world had been integrated into the capitalist market and brought into capitalist production relations. No countries or regions remained outside of world capitalism, and there were no longer any pre- or noncapitalist modes of production on a significant scale [6].

Underlying this perspective is his argument that the essence of capitalism is 'production undertaken through a particular form of social interaction, what I will call the capital-labor relation (or capitalist production relations), in order to exchange what is produced, commodities, in a market for profit' [5]. ${ }^{3}$ He argues on this basis that

Capitalist production relations are replacing what remains of precapitalist relations around the globe. The era of the primitive accumulation of capital is coming to an end. Those cultural and political institutions that fettered capitalism are being swept aside, paving the way for the total commodification, or marketization, of social life worldwide [7].

These claims (all at the very least misleading, as we shall shortly see) underpin his argument that globalization represents a shift from a world to a global economy, 'a new, transnational phase in the development of the world capitalist system, [a] defining feature [of which] is the rise of transnational capital' [9].

However, this is a flawed hybrid perspective, which grafts onto a garbled version of the Marxist understanding of capitalism as 'essentially a production relation' [8] an incompatible conception of transnationalism taken from the contemporary sociology of globalization (and in particular from Castells, Dicken and Sklair, who feature prominently as sources and interlocutors throughout). And because the understanding of the 'capital-labour relation' he employs is defective, the graft does not take.

In talking as he does of peoples around the world being 'brought into capitalist production relations' Robinson ignores the vital distinction between the formal and the real subsumption (or subjection) of labour to capital. It is one thing for forms of production which arise outside capitalism to be brought under its control

'The capital-labor relation is the relationship between workers and capitalists as they come together in the process of producing goods that people want or need' [5]. 
- as for example in the use 'global capital' makes of informal sector activity, home-working, or patriarchal sweatshops. Capital in this case appropriates the product, but the production process itself is not 'the specifically capitalist mode of production in its developed form'. ${ }^{4}$ That is to say, it does not feature 'factory production' - the revolutionary development which features the increasing application of machinery (capital) to the production process, rising productivity, and a fundamental switch in the character of exploitation (and the source of profit) from the extraction of absolute surplus value to the extraction of relative surplus value. There is an enormous difference, which Robinson's use of the term 'capital-labour relation' to cover both situations overlooks, between the capitalist appropriation of home-working or informal sector production (which is certainly a feature of global commodity chains), and the installation of factory production and the specifically capitalist dynamic of the increasing application of capital to the production process itself (which may or may not be, and often is not). ${ }^{5}$ Once this distinction is introduced, Robinson's argument falls to pieces.

First, there is no universal 'new global capital-labor relation' [19]: the claim that 'capitalist production relations are replacing what remains of precapitalist relations around the globe' conflates two fundamentally different processes, assuming homogeneity where in fact heterogeneity still prevails. Robinson presents no evidence to suggest that the production networks and commodity chains he talks about feature capitalist relations of production' in their developed form' throughout. He can't, because they don't. He talks instead about 'the global casualization or informalization of labour', which 'involves alternative systems of labor control and diverse contingent categories of labor' [19] - in other words, he acknowledges the diversity of the social relations of production involved. ${ }^{6}$

4 Marx [1976], p. 1019.

5 'With the production of relative surplus-value the entire real form of production is altered and a specifically capitalist form of production comes into being (at the technological level too). Based on this, and simultaneously with it, the corresponding relations of production between the various agents of production and above all between the capitalist and the wage-labourer, come into being for the first time' [ibid., p. 1024]. The definition of the global proletariat that Robinson adopts from Hardt and Negri ignores this distinction. They define it as 'a broad category that includes all those whose labor is directly and indirectly exploited by and subject to capitalist norms of production and reproduction' (cited p. 44 from Hardt and Negri, 2000, p. 52; emphasis mine).

6 Robinson adds later, in a passage laden with examples of reliance on the extraction of absolute surplus value, that "Well-known trends associated with the restructuring of the labor-capital relation taking place under globalization include "downward levelling," deunionization, "ad hoc" and "just-in-time" labor supply, the superexploitation of immigrant communities as a counterpart to capital export, the lengthening of the working day, the rise of a new global "underclass" of supernumeraries or "redundants" subject to new forms of social control, and new gendered and 
Transnationalization may involve 'the functional integration of .. internationally dispersed activities' [14] but it doesn't necessarily involve the universalization of the capital-labour relation specific to capitalism. Robinson draws on Castells' notion of the ability of the global economy 'to work as a single unit in real time, making possible simultaneity and therefore real organic integration', and Dicken's contrast between shallow and deep integration of the global economy [14], but he does not substantiate the claim that 'globalization is unifying the world into a single mode of production' [15]. ${ }^{7}$

Third, it is misleading to claim that the 'cultural and political institutions that fettered capitalism are being swept aside, paving the way for the total commodification, or marketization, of social life worldwide'. By presenting this as a process which is irreversibly under way, Robinson again skips over the issue of the agency behind the process. Yet in much of the world existing social relations, sustained by powerful cultural and political institutions, still stand in the way of the universalisation of the 'specifically capitalist mode of production'; and 'global capital' often supports, perpetuates and benefits from them.

Fourth, then, Robinson is wrong to claim that a shift is taking place from a world to a global economy, if by this he means that whereas in the past world economy nation-states 'mediated the boundaries between a world of different national economies and articulated modes of production', now they do not [10]. This fundamentally misleading suggestion arises from looking only at the alleged opposition between national and transnational fractions of capital, and forgetting for the moment the crucial role that national states still play in enforcing the hegemony of capital over labour within their own territories.

\section{Transnationalism and the transnational state}

Robinson's argument depends simultaneously, then, on two diametrically

racialized hierarchies among labor' [102].

7 For this reason, the case Robinson makes for the claim that we are living in a new epoch is not persuasive. I argue that we are indeed living in such an epoch, but one characterized by a dynamic of global competitiveness [Cammack, 2003, 2006c]. The global project espoused by the international institutions is addressed explicitly to the real subsumption of labour to capital and the increased extraction of relative surplus value on a global scale. But individual capitalists, including those at the centre of the advanced capitalist countries, still resort to all means available in their pursuit of profit and of competitiveness, including continued and in some cases increased reliance on very primitive methods of production. Similarly, it is no paradox that while the international institutions rail against bribery and corruption, major transnational corporations continue to employ it on a massive scale, with the tacit and sometimes explicit support of their governments. These are simply indications of the contradictions of global capitalism, reflecting both the dynamics of uneven and combined development, and the relative autonomy of the international institutions and their project from particular existing capitals. 
opposed understandings of the idea of 'transnationalism' - one narrow and specific, allegedly deriving from classical Marxism, and centred on the idea of the spread of 'global capital' and of strictly capitalist relations of production; the other broad and general, deriving from the contemporary sociology of globalization, and including all manner of practices and processes not contained within borders. His argument hinges on the first, but his 'evidence' relates to the second, though even here it does not go beyond the entirely uncontroversial claim that capitalist production is no longer 'national' in character.

So although he prefaces his review of the empirical evidence for his argument with the statement that 'we need to focus on the production relations that underpin market relations and the social forces that drive production relations in order to identify what is qualitatively new in the current epoch' [22], he looks at neither. Instead, he takes FDI as a proxy for transnational production, on the grounds that by definition it 'transnationalizes production' [22]. Well, it depends what you mean. There is case to be made (indeed, Marx made it) that foreign investment introduces capitalist relations of production into societies where they do not prevail, but Robinson does not pursue it. Instead he throws into his conception of transnationalization TNC reliance on local sources of funding, outsourcing and subcontracting [22-3; cf. 54], and the fact that world exports have been growing faster than world production [24], now arguing after all he has said about production that '[t]rade and FDI are in many respects the most important mechanisms of globalization and transnational integration' [23]. The focus has already switched from the universalization of capitalist relations of production to the integration of different regions into the world market.

Even here, though, the pattern of integration proves highly skewed. Remarking that world FDI inflows reached $\$ 1.27$ trillion in 2000, Robinson notes that some 80 per cent of this total was concentrated in North America, Europe and Japan. He does not consider the implication that only a minor proportion of FDI is potentially effecting a revolution in relations of production around the world, and that if anything the differential patterns of investment might be reinforcing rather than effacing heterogeneity. The same point applies to the data he later provides on cross-border mergers as evidence of the emergence of the TCC [57-62].

Turning to trade, Robinson argues that the growing significance of TNC-initiated or intra-firm trade is further evidence of globalized production, but states again that much of it involves subcontracting, licensing, franchising and outsourcing 
[28]. All well and good. But the issue on which this evidence is intended to bear is the production relations that underpin market relations, and the social forces which drive them. Never mind that Robinson also concedes that the majority of trade in the world still takes place within rather than across national boundaries' [29]. Damaging though that is to the argument, the more important point is that there is nothing to support the proposition that the social relations of production around the world are reaching a point of virtually total transformation, such that capitalist relations of production proper are dominant.

No one will doubt that the developments in global production, trade and investment which Robinson describes have consequences for relations of production around the world. But having first announced that this is his concern, Robinson makes no effort to investigate it, instead counting a whole range of different forms of production as falling within the ambit of 'transnational capital'. Is FDI originating in the 'capitalist core' having a transformative effect on the social relations of production in 'peripheral' or 'developing' economies? To what extent do such economies exhibit an increase in strictly capitalist relations of production? What proportion of the global workforce is subject to such relations of production, and how is it distributed? What evidence is there for the proposition that global capitalists wish to see all 'non-capitalist' forms of labour eliminated? Such evidence as he presents actually goes against him, as he appears to think himself that capital benefits from such heterogeneity in the global system. ${ }^{8}$

Worse still, Robinson's subsequent presentation of empirical evidence of TCC formation revolves around exactly the same material (sometimes, as at pp. 1920 and 68, repeated word for word) - the spread of TNCs in the developed and developing world, cross-border mergers and alliances (almost entirely in the developed world), interlocking directorates, and strategic alliances. Further evidence of the global reach of capital, but, as Robinson himself tells us, not sufficient 'to prove the existence of a TCC' [54].

What can we make, then, of the claims made for the 'transnational capitalist class'? As Robinson himself reminds us [35-7], the idea of a capitalist class that has transcended national boundaries and operates on a global scale is not new.

\footnotetext{
8 For example, he argues that the mobility of capital allows it 'to search out the most favourable conditions for different phases of globalized production, including the cheapest labour, the most favourable institutional environment (e.g., low taxes) and regulatory conditions (e.g. lax environmental and labor laws, a stable social environment, and so on' [22].
} 
What is at issue, then, is what is new in what he has to tell us about it - the context out of which it emerges, the interests it has, its degree of coherence, its capacity to act as a class, and the manner in which it relates to the state. As we shall see, in each of these areas his only idea is that of the 'supersession' of the national state (although the claim is no sooner made in each area than it is retracted), and on each the approach taken is one-dimensional, mechanistic and reductionist. $\mathrm{He}$ is unable to convince us that capitalists no longer have an interest in the national state, and he does not even try to demonstrate that they have a capacity to act as a class beyond it.

First, as noted above, Robinson reduces the issue of bourgeois class identity and interest to an opposition between national and transnational class fractions $[37,49]$, and argues that 'as the entire circuit [of capital accumulation] becomes transnationalized, so too do classes, political processes, states, and culturalideological processes' [39]. There is a huge confusion here (parallel to that over the formal versus real subsumption of labour to capital) which originates in the notion that the link between production and territory has been broken. As Robinson develops the argument that the capitalist class is 'increasingly less tied to territoriality or driven by national competition' [36] he talks as if production had become extra-terrestrial rather than spread across numerous territories. In doing so, he momentarily tricks himself into thinking that capitalists (however much or little they might be identified with a particular nation state) have no interest in the local state in any territory in which they are active. Rather, the TCC has 'an objective class existence and identity in the global system above any local territories and politics' [47, emphasis mine]. As much else of what he has to say shows clearly, he does not actually think this all the time. But the fact remains, dispute it as he might, that the argument for a 'transnational capitalist class' depends upon the bizarre notion that its activity has become deterritorialized. ${ }^{9} \mathrm{He}$ is quite right to make the uncontroversial point that the idea of a 'national bourgeoisie' does not capture much of the reality of contemporary political economy, but quite wrong to assume that this means that the link between capitalists and national (local) states is severed, or that capital is somehow 'liberated from the nation-state' [39].

Second, he falls all the more readily into this error because although he dates

9 Thus Robinson refers to 'transnational or deterritorialized' class interests [53], and argues that transnationalization 'disembeds [national capitals] from their locations and locates them in new supranational space' [54]. 
the period of state-centrism from the Treaty of Westphalia [90], in practice he reduces the national state, in its relation to capitalism and the bourgeoisie, to the Fordist-Keynesian interventionist state (or the developmental state in the Third World), and mistakenly interprets the 'end' of this state as the end of the national state altogether. The logic is crudely mechanistic - the 'national bourgeoisie' needed the Fordist-Keynesian state to guarantee the conditions for national accumulation and legitimation, but now that transnational capital is dominant, there is no need for it any more. ${ }^{10}$ However, the role of the national state in guaranteeing the conditions of accumulation and legitimation (or, rather, in seeking to do so, if it so happens that that is what it does) goes beyond arbitrating between 'national' and 'global' capital, and in general beyond the specific form it takes at a particular place and time. And Robinson is actually well aware that local/national states do indeed still seek to secure these conditions, and that they do so now, increasingly, through neoliberal strategies in the context of 'post-Fordism'.

The tension this equivocation over the continued role of the national state generates for Robinson's 'transnational' theory is precisely reflected in the way in which he alternates between the claim that it has been superseded [45, 46, 9092] and the very different claim that it has been modified, reorganised or transformed $[50,74,75,100,121-125]$. He recognises that the national state still mediates class relations in a way that is fundamental for capital, global or otherwise, when he states that 'the mediating element of national states has been modified' [43], and when he notes that 'the principal social contradiction is still between dominant and subordinate classes' [53]. He recognises it, too, when he charts the shift from welfare and developmentalist to neoliberal states around the world [121-5]. But he forgets it when he chides realists, world-system analysts and Marxists alike with thinking that 'hegemony is inextricably tied up with state power, and state power is conceived in terms of the nation-state' [76], giving as his reason only the obsolescence of the idea of the global system as a 'competing nation-state system' [77]. This comes of drinking too deep from the

\footnotetext{
10 There is a telling hiatus in the development of the argument on this point. Robinson is clear that national Fordism and the associated Fordist class compromise is defunct. But his account of its demise, which invokes Polanyi's notion of the 'double movement', breaks off when he reaches the 'first movement' of the great neoliberal transformation, or the 'maturation of transnational capitalism'. He does not go on at this point to consider whether this shift might be followed by a 'second movement', or in other words by a global Fordist class compromise [40-44]. When he does, over a hundred pages later [163-8], he is disappointingly agnostic.
} 
spring of international political economy (Cox appears to figure here as a representative 'Marxist'), and overlooking for the moment the different emphasis of a Marxist approach. Here as elsewhere, he can only see what his flawed methodology will let him see. Once he opts to relocate global capital to an imagined 'new supranational space', he is compelled, on pain of theoretical extinction, to imagine a transnational or supranational state through which it can operate.

On his own account, though, the national state has adapted very readily to the neoliberal age, and is almost universally facilitating the activity of global capital. Indeed, he argues explicitly that transnational fractions of local elites and capitalist classes swept to power in a number of countries in the $1980 \mathrm{~s}$ and 1990s, and 'captured the "commanding heights" of state policymaking: key ministries and bureaucracies in the policymaking apparatus, especially central banks and finance and foreign ministries, as key government branches linking countries to the global economy' [49]. As I shall say below, this is too simplistic. But the fact is that he does claim that transnational blocs became hegemonic in the vast majority of countries and set out to thoroughly transform their countries, using national state apparatuses to advance globalization and to restructure and integrate them into the global economy' [ibid, emphasis mine]. ${ }^{11}$ If so, it follows directly that there is no need for a transnational state at all, and no reason to predict the demise of national states. Robinson has been too absorbed by banging his head against the imaginary brick wall of 'state centrism' to notice that his own argument demolishes the case for a transnational state. In sum, Wood [1999, cited p. 46] and others are right about the continuing centrality of the national state, and Robinson [88-93] is wrong. And this in turn explains perfectly well what otherwise in an insoluble conundrum for Robinson the fact that on the one hand the TCC is inchoate and the TNS only starting to take shape, while on the other the whole set-up is working like a dream, as if it were fully formed, to meet the needs of global capital.

I suggested just above, however, that his approach is too simplistic. To the

11 Typically, the same point is restated later, but supported by the opposite argument - that capital has abandoned rather than captured the national state, and the national state has responded by changing its orientation: 'As capital became liberated from the nation-state and assumed tremendous new power relative to labor with the onset of globalization, national states shifted from reproducing Keynesian social structures of accumulation to servicing the general needs of the new patterns of global accumulation and the TCC, involving a rollback of redistributive projects' [74-5]. 
constant detriment of the argument, Robinson is a thoroughgoing instrumentalist - in other words, he conceives of the state, whether national or transnational, as captured by and acting as an agent of the capitalist class. So at the national level

Once they have been captured by transnational groups, national states internalize the authority structures of global capitalism; the global is incarnated in local social structures and processes. The disciplinary power of global capitalism shifts the actual policymaking power within national states to the global capitalist bloc, which is represented by local groups tied to the global economy [50].

Robinson does not attempt to explain or even illustrate the mechanism by which this act of demonic possession takes place, despite its centrality to his argument. And as argued above, he cannot easily argue both that transnational capital has captured and is using national states, and that national states are in the process of being superseded by a transnational state because the needs of capital have changed. Worse, he overlooks the possibility that national states are not acting under the control of transnational groups, but instead are acting with relative autonomy from them to impose the disciplines of global competitiveness on all classes, capitalists included [Cammack, 2006c]. This is consistent with the view that national states are currently strengthened, encouraged and supported in this orientation by an increasingly closely coordinated network of international agencies and institutions. On this logic, there is no reason either to describe the network of institutions around and beyond national states as a 'state', or to expect anything more centralized to emerge.

Robinson cannot grasp this, because he is the prisoner of a relentless false logic: capital needs a state to act in its general interest; capital is now transnational; so capital needs a transnational state. His lack of consistency on these points involves him in a fatal contradiction. He states that the TNS apparatus has already arisen under the auspices of the TCC, and that the transnational managerial elite which represents the TCC already 'exercises authority over global institutions, and controls the levers of global policymaking [48]. The 'transnational ruling bloc' is already the agent of a revolution from above, 'aimed at promoting the most propitious conditions around the world for the unfettered operation of the new global capitalist production system' through 'modifications made from above in global social and economic structures through the agency of TNS apparatuses' [77]. Yet this is the very same class whose boundaries are indeterminate [54], and whose existence is not yet proven. But 
note, again: if we accept these claims, unsubstantiated though they are, there is still no reason to believe that a 'transnational state' will evolve in any more concrete or centralized form that it already has. Whatever Robinson may say to the contrary, his argument requires that the transnational state already exists.

It is not surprising, in the light of all this, that when Robinson finally tells us what he means by the 'transnational state' through which the global bourgeoisie rules, it turns out not to be a state at all, but a loose yet all-encompassing conglomeration of global institutions, nation states, and other agencies:

This TNS apparatus is an emerging network that comprises transformed and externally integrated national states, together with the supranational economic and political forums, and has not yet acquired any centralized institutional form. The economic forums include the IMF, the WB, the WTO, the regional banks, and so on. The political forums include the Group of Seven (G-7) countries and the larger group of 22 countries, among others, as well as the U.N. system, the OECD, the EU, the Conference on Security and Cooperation in Europe (CSCE), and so on [88].

Whatever else this is, it is not a state, transnational or otherwise. Yet Robinson goes on immediately to claim that the TCC (the very same one that is inchoate or even non-existent) 'has directly instrumentalized this TNS apparatus', and 'has been attempting to forge a new global capitalist historic bloc' through these global institutions. And lest we should mistake his meaning, he gives as his first proposition of his thesis on the TNS that:

Economic globalization has its counterpart in transnational class formation and in the emergence of a TNS, which has been brought into existence to function as the collective authority for a global ruling class [ibid]. ${ }^{12}$

There is only one word for this: twaddle. And it should be noted that this is not a first rough approximation of the idea, but a considered statement of Robinson's position, maintained over a number of years [cf. Robinson, 1998], and juxtaposed to a passage which shows beyond question that the 'TNS' is neither collective, nor remotely capable of exercising authority. What evidence does Robinson offer, then, in support of this unlikely proposition? Well, none to speak of. Instead we get a very pedantic lecture on nation-state centrism [88-93], a disquisition on Weber and Marx [94-9] which touches on instrumentalism, structuralism and relative autonomy without mentioning, let alone qualifying, his

\footnotetext{
12 Propositions 2 and 3 state that 'The nation-state is neither retaining its primacy nor disappearing but is being transformed and absorbed into the larger structure of a TNS', and that 'The emergent TNS institutionalizes the new class relation between global capital and global labor' [88].
} 
own claim that the TCC has directly instrumentalized the TNS apparatus, and a re-run through the component elements of the TNS, with a couple of new ones added for good measure [100-101]. Robinson then returns to the issue of the capital-labour relation and its management by the national state [102-10], repeating large chunks of material from earlier chapters, and again identifying the nation-state as a 'fetter to accumulation' in the latter decades of the twentieth century before describing in great detail how it has since reinvented itself in such a way that the continued existence of the nation-state serves numerous interests of a TCC' [106]. And we learn here, courtesy of a brief discussion of Proposition 187, that 'national and local territorial boundaries and political jurisdictions that in the past may have thrown up barriers to global accumulation have become functional to the globalized circuits of capital' [107]. Leaving aside the suspicion that this smacks rather of 'nation-state centrism', let's just say the conclusion offered above is amply confirmed: the TNS is an unnecessary theoretical construct.

Let me offer a specific example, along with a thought experiment. When Robinson eventually turns to 'some empirical reference points' for the emergence of a TNS, he tells a familiar tale - the emergence of global financial markets, the reorientation of IFIs and other supranational institutions, and the shift from welfare and developmentalist to neoliberal states. The latter section leads up to the following statement:

Hence, far from the end of the nation-state ... we are witness to its transformation into neoliberal states. These neoliberal states as components of a TNS provide essential services for capital. These neoliberal states, acting as transmission belts and filtering devices for the transnational agenda, function as components of a TNS. They provide essential services for capital within specific national territories [124-5, emphasis mine].

Now try the same passage again, but with the repetition and the references to the TNS removed:

Hence, far from the end of the nation-state ... we are witness to its transformation into neoliberal states. ... These neoliberal states provide essential services for capital within specific national territories [124-5, emphasis mine].

What have we lost? Nothing, I submit, except confusion, redundancy, crude and unsubstantiated instrumentalism - and the phantom transnational state. 


\section{Setting Robinson straight}

Robinson describes a world in which capital has already transcended the previous link between production and territoriality, in which the national 'Fordist class compromise' has already been abandoned, and in which national states have already adopted a neoliberal orientation. It follows that if the 'transnational state' does not yet exist, there is no need to invent it.

The switch that he needs to make, then, is not from 'the nation-state and the interstate system' [88] to the 'transnational state' but from the nation-state and the interstate system to the nation-state and the global system. He is right to remark that 'the nation-state is a historically bound phenomenon' [90], but wrong to claim that it is fated to depart the historical stage at this particular point in time, and wrong to substitute homilies on reification for analysis of the actual 'complex, changing set of social relations' [90-91] that current practice is creating. In the present era, this entails thinking of the national state not as an instrument or agent of capital, whether national or global, but in relation to the logic of global competitiveness [Cammack, 2006c]. The re-orientation of states towards this logic certainly entails a re-orientation towards labour. But more than that, it entails the imposition of the disciplines of capitalist competition across all classes - on the working class, for sure, and not just on 'national' capitalists (as reflected in the ending of support for 'national Fordism which he describes), but on capital in general, national or not. The fact that every one of the various bodies Robinson identifies as making up the TNS (p. 11 above) is focused on the reform and reinvigoration of national states should give him pause for thought. This is indeed a new epoch in the development of capitalism, but one not dreamed of in Robinson's philosophy. It is one in which states around the world are led, or driven, to offer 'better climates for investment' - one in other words in which states indeed no longer mediate 'the boundaries between a world of different national economies and articulated modes of production' [10], but rather compete directly with each other to offer the best site for accumulation in an integrated global capitalist economy.

To grasp what is really going on, then, Robinson would need to be more aware of the orientation over the last ten years of the international institutions he airily designates as agents of the 'transnational capitalist class' than he is. He would then notice that these increasingly coordinated international organizations are seeking to advance capitalism 'in its most developed form' on a genuinely global 
scale [Cammack, 2002]; that they are therefore not so much instruments of a transnational capitalist class as relatively autonomous bearers of a broader global capitalist project [Cammack, 2003]; and that their energy has been devoted for over a decade not to imposing the 'Washington Consensus', but to seeking to devise and promote strategies for converting national states into viable agents of capitalist reforms at home compatible with competitiveness on a global scale [Cammack, 2004, 2006c]. This does not do away in the slightest with 'competition between states', but it changes its character:

In the context of the completion of the world market and the universalisation of the imperatives of capitalist competition, autonomous projects for capitalist accumulation secured at the level of the state - which, in any case, have been only briefly possible in a small number of countries in the past - are generally problematic. At the level of global economic management, this situation is reflected in the emergence of global regulatory agencies (international organisations), and regional and inter-regional initiatives sponsored and carried forward by state leaders in an effort to mitigate the difficulties they face in what they take to be their 'national interest'. States naturally carry into this institutional environment their need to compete with each other, as well as their need to establish the general conditions for the global hegemony of capitalism [Cammack, 2003, p. 40].

If Robinson could entertain the possibility that states have changed but are still central, the odd snippets he quotes directly from the remarkably few primary sources on which he draws for evidence of the reorientation of the international financial institutions and UN agencies would start to make sense. He would see, for instance, that when the World Bank's 1997 World Development Report states that the restructuring of key state agencies 'can mostly be achieved through executive order' [123], and remarks that 'globalization begins at home' [125], it is recognizing that the national state is central to the project of building a globally competitive capitalism; and that UNDP support for 'entrepreneurial cultures in which the private sector has historically been largely absent or underdeveloped' [116] is not evidence of the UNDP acting at the behest of global capital, but reflects rather a broader strategy aimed at what it actually says it is - building strong entrepreneurial cultures in every country, or in other words promoting global competitiveness (Cammack, 2006a).

He would then be in a position to see that it is because national states are envisaged as the lead agents in the process, called upon precisely to reform the 'cultural and political institutions that fetter capitalism', or in other words to 
institute at national level the conditions that enhance global competitiveness, that the objective of the international institutions and their allies in the G8 and elsewhere is to endow them everywhere, in the developed and developing world alike, with the capacity both to impose capitalist discipline, and to secure legitimacy [Cammack, 2006b]. This is not a project that will necessarily succeed. But although there is no reason to expect national states to last for ever, there is no immediate alternative candidate to play these roles - certainly not the imagined 'transnational state'. Were it not for the fact that he is periodically dazzled by it, and permanently in thrall to a crude instrumentalism, he might have seen some of this. He might then have avoided the mess he is in, in which a state that does not yet exist is already a precision instrument in the hands of an already omnipotent class that is only in the early stages of a process of formation.

\section{Conclusion}

Little has changed since Robinson published the monograph that has been my principal focus here. He continues to insist on the need to deploy the concepts of transnational capitalist class and transnational state [Robinson, 2005a], and to see nation states as the effective agents of transnational capital:
historical analysis reveals that in the momentary conjuncture of the late $20^{\text {th }}$ and early $21^{\text {st }}$ century, transnational capital and its representatives did come to capture most state apparatuses around the world in a historically unprecedented way and to utilise these national state policy-making apparatuses to advance capitalist globalisation, including developing sets of policies functional to the global accumulation of capital [Robinson, 2006, p. 531-2].

At the same time he accuses his opponents of theoreticism, in the sense of developing analyses and propositions to fit theoretical assumptions, rather than to illuminate reality [ibid, p. 532]. In fact, the argument goes precisely the other way - it is Robinson who has stuck doggedly over a decade to the defence of a theoretical position which is neither coherent nor empirically grounded. He should acknowledge that his own focus on the transformation of national states does not need it, and drop it. In doing so, he would remove what threatens to become a major distraction from the task of understanding what is indeed a new epoch in global capitalism. 


\section{References}

Cammack, Paul, 2002. 'Attacking the Poor', New Left Review, second series, No. 13, Jan-Feb, 125-134.

Cammack, Paul, 2003. 'The Governance of Global Capitalism', Historical Materialism, 11, 2, 37-59.

Cammack, Paul, 2004. 'What the World Bank Means by Poverty Reduction, and Why it Matters', New Political Economy,

Cammack, Paul, 2006a. 'UN Imperialism: Unleashing entrepreneurship in the developing world', in C. Mooers, ed, The New Imperialists: Ideologies of Empire (Oxford: Oneworld Publications).

Cammack, Paul, 2006b. 'Global Governance, State Agency and Competitiveness: the Political Economy of the Commission for Africa', British Journal of Politics and International Relations, 8, 3, 331-350.

Cammack, Paul, 2006c. 'The Politics of Global Competitiveness', Papers in the Politics of Global Competitiveness, No. 1, Institute for Global Studies, Manchester Metropolitan University, e-space Open Access Repository.

Hardt, Michael and Antonio Negri 2000. Empire [Cambridge: Harvard University Press].

Marx, Karl, 1976 [?1863-6]. 'Appendix: Results of the Immediate Process of Production', in Capital, Vol. 1 (London: Penguin/New Left Review), pp. 9481084.

Robinson, William I. 1998. 'Beyond nation-state paradigms: globalization, sociology and the challenge of transnational studies', Sociological Forum, $13,4,561-594$.

Robinson, William I. 2000. 'Towards a global ruling class: globalization and the Transnational Capitalist Class', Science \& Society, 64, 1, 11-54.

Robinson, William I. . 'Social theory and globalization: the rise of a transnational state', Theory and Society, 30, 157-200.

Robinson, William I. 2002. 'Global Capitalism and Nation-State Centric Thinking: What We Don't See When We Do See Nation-States: Response to Critics', Science and Society, 65, 4, 500-508.

Robinson, William I. 2004. A Theory of Global Capitalism: Production, Class and State in a Transnational World (Baltimore and London: Johns Hopkins University Press).

Robinson, William I. 2005a. 'Global capitalism: the new transnationalism and the folly of conventional thinking', Science \& Society, 69, 3, 316-328.

Robinson, William I. 2005b. 'Gramsci and Globalisation: from nation-state to transnational hegemony', Critical Review of International Social and Political Philosophy, 8, 4, 559-574.

Robinson, William I. 2006. 'Reification and Theoreticism in the Study of Globalisation, Imperialism and Hegemony: Response to Kiely, Pozo-Martin and Valladão', Cambridge Review of International Affairs, 19, 3, 529-533.

Wood. Ellen Meiksins, 1999. 'Unhappy Families: Global Capitalism in a World of Nation-States', Monthly Review 51, 3, 1-12. 


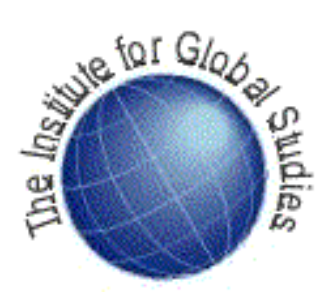

Papers in the Politics of Global Competitiveness

Institute for Global Studies

Manchester Metropolitan University

e-space Open Access Repository

http://www.e-space.mmu.ac.uk

\section{Papers in the Politics of Global Competitiveness}

1. The Politics of Global Competitiveness

Paul Cammack

Nov 2006

2. UN Imperialism: unleashing entrepreneurship in the

Paul Cammack

Dec 2006 developing world

3. Forget the Transnational State

Paul Cammack

Jan 2007

(C) Paul Cammack 2007. May nt be used for commercial purposes. May be freely copied and distributed provided that the original author is given credit.

\section{Cite as:}

Paul Cammack, 'Forget the Transnational State', Papers in the Politics of Global

Competitiveness, No. 3, Institute for Global Studies, Manchester Metropolitan University, e-space Open Access Repository, 2007.

This document was produced using Open Office Writer, an Open Source programme which is part of the Open Office Suite (http://www.openoffice.org) 